\title{
Intermetallic Compounds Formed at the Interface between Liquid Indium and Copper Substrates
}

\author{
C.L. YU, S.S. WANG, and T.H. CHUANG \\ Institute of Materials Science and Engineering, National Taiwan University, Taipei 106, Taiwan, \\ Republic of China.
}

The interfacial reactions between liquid $\mathrm{In}$ and $\mathrm{Cu}$ substrates at temperatures ranging from $175^{\circ} \mathrm{C}$ to $400^{\circ} \mathrm{C}$ are investigated for the applications in bonding recycled sputtering targets to their backing plates. Experimental results show that a scallop-shaped $\mathrm{Cu}_{16} \mathrm{In}_{9}$ intermetallic compound is found at the $\mathrm{Cu} / \mathrm{In}$ interface after solder reactions at temperatures above $300^{\circ} \mathrm{C}$. A double-layer structure of intermetallic compounds containing scallop-shaped $\mathrm{Cu}_{11} \mathrm{In}_{9}$ and continuous $\mathrm{CuIn}$ is observed after the $\mathrm{Cu} / \mathrm{In}$ interfacial reaction at temperatures below $300^{\circ} \mathrm{C}$. The growth of all these intermetallic compounds follows the parabolic law, which implies that the growth is diffusion-controlled. The activation energies for the growth of $\mathrm{Cu}_{16} \mathrm{In}_{9}, \mathrm{Cu}_{11} \mathrm{In}_{9}$, and CuIn intermetallic compounds calculated from the Arrhenius plot of growth reaction constants are $59.5,16.9$, and $23.5 \mathrm{~kJ} / \mathrm{mole}$, respectively.

Key words: $\mathrm{Cu} / \mathrm{In}$ interface, soldering reaction, intermetallic compound

\section{INTRODUCTION}

For the bonding of recycled sputtering targets to copper backing plates, soldering has been commonly employed as a low-temperature joining method. Pure indium is a popular solder for this application due to its lower melting point, greater ductility, and longer thermal fatigue life. ${ }^{1-3}$ During the soldering process, intermetallic compounds form at the solder/substrate interface, which is assessed to be a sign of good connection in the solder joints. However, an overgrowth of intermetallic compounds will result in brittle fracture at the interface. It also increases the difficulty in further recycling of the costly indium solder material.

The interfacial reactions between $\mathrm{Cu}$ and In have been reported in the literature. Vianco et al. studied the intermetallic compounds formed during the solid-state reaction in a $\mathrm{Cu} / \mathrm{In}$ diffusion couple. ${ }^{4}$ At an annealing temperature of $70^{\circ} \mathrm{C}$, a metastable composition of $\mathrm{Cu}_{9} \mathrm{In}_{16}$ was observed at the interface and subsequently turned into a dual-layer structure of $\mathrm{Cu}_{9} \mathrm{In}_{16}$ joined by an intermetallic compound, $\mathrm{Cu}_{11} \mathrm{In}_{9}$, at $100^{\circ} \mathrm{C}$. At $135^{\circ} \mathrm{C}$, it transforms into $\mathrm{Cu}_{11} \mathrm{In}_{9}$. The growth of the intermetallic compound was diffusion-controlled, and its apparent activation

(Received August 10, 2001; accepted January 16, 2002) energy was $20 \mathrm{~kJ} / \mathrm{mol}$. In the temperature range between $100^{\circ} \mathrm{C}$ and $150^{\circ} \mathrm{C}$, Manna et al. found the formation of $\mathrm{Cu}_{11} \mathrm{In}_{9}$ at the interface between an In thin film and a $\mathrm{Cu}$ single crystal. ${ }^{5}$ The growth of the intermetallic compound also followed a parabolic relationship with an apparent activation energy of 26 $\mathrm{kJ} / \mathrm{mol}$.

With respect to the soldering reaction between liquid $\mathrm{In}$ and a $\mathrm{Cu}$ substrate, Kao dipped $\mathrm{Cu}$ disks into In and $\mathrm{In}+\mathrm{Cu}$ baths at $200^{\circ} \mathrm{C}^{6} \mathrm{Cu}_{11} \mathrm{In}_{9}$ was identified at the interface after both reactions. Su et al. found that the resulted intermetallic compound was $\mathrm{Cu}_{11} \mathrm{In}_{9}$ by heating the $\mathrm{Cu} / \mathrm{In}$ couple at $300^{\circ} \mathrm{C}$.

With respect to the $\mathrm{Cu} / \mathrm{In}$ thin film reactions, rapid formation of the CuIn intermetallic compound was observed by Roy $^{8}$ and Chen. ${ }^{9}$ They found that the CuIn intermetallic compound forms even at room temperature. However, the CuIn phase was not shown on the $\mathrm{Cu}$-In phase diagram. Roy et al. investigated $\mathrm{Cu} / \mathrm{In}$ thin film reactions by measuring the change of electrical resistance with time, where the growth of CuIn was confirmed by $\mathrm{x}$-ray diffraction and transmission electron microscopy. Chen et al. developed a $200^{\circ} \mathrm{C}$ fluxless process to produce $\mathrm{Cu}-\mathrm{In}$ joints and discovered that CuIn intermetallic compounds were formed immediately after depositions of $\mathrm{Cu}$ and $\mathrm{In}$ thin films. 
The efforts of this study are concerned with the identification of intermetallic compounds formed at the $\mathrm{Cu} / \mathrm{In}$ interface after solder reactions in a wide temperature range between $175^{\circ} \mathrm{C}$ and $400^{\circ} \mathrm{C}$. For this purpose, the morphology and growth kinetics of the intermetallic compounds are investigated. Their composition distributions are also analyzed by electron probe microanalysis (EPMA).

\section{EXPERIMENTAL}

High-purity $\mathrm{Cu}$ substrates (99.95\%) were cut to the size of $8 \mathrm{~mm} \times 6 \mathrm{~mm}$ with a thickness of $0.8 \mathrm{~mm}$. They were ground with 1500 mesh $\mathrm{SiC}$ paper and polished

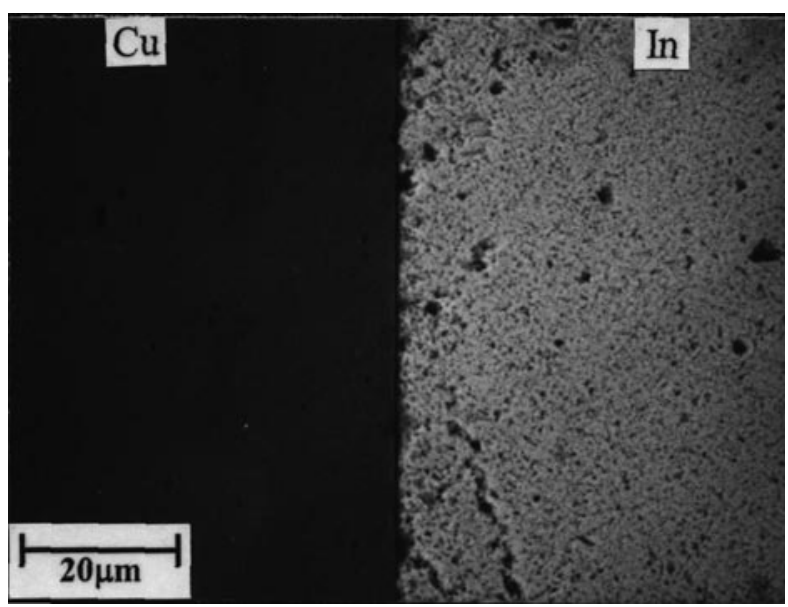

a

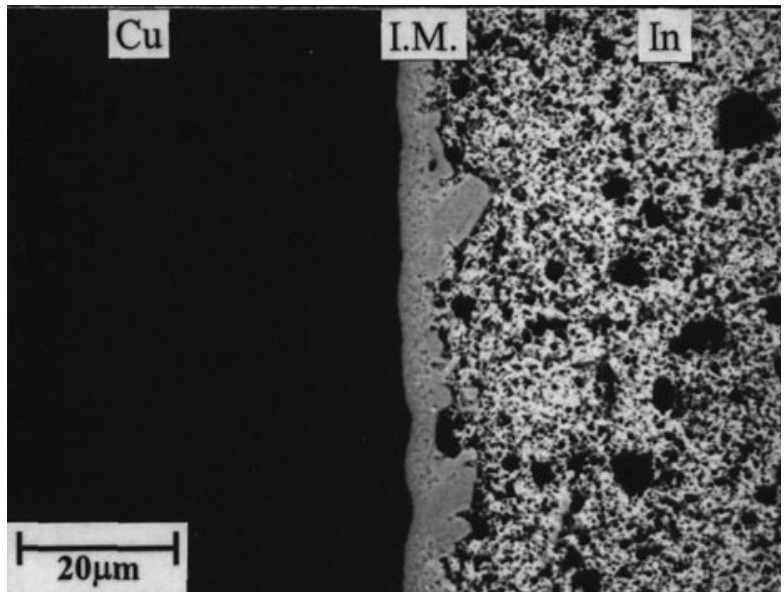

C

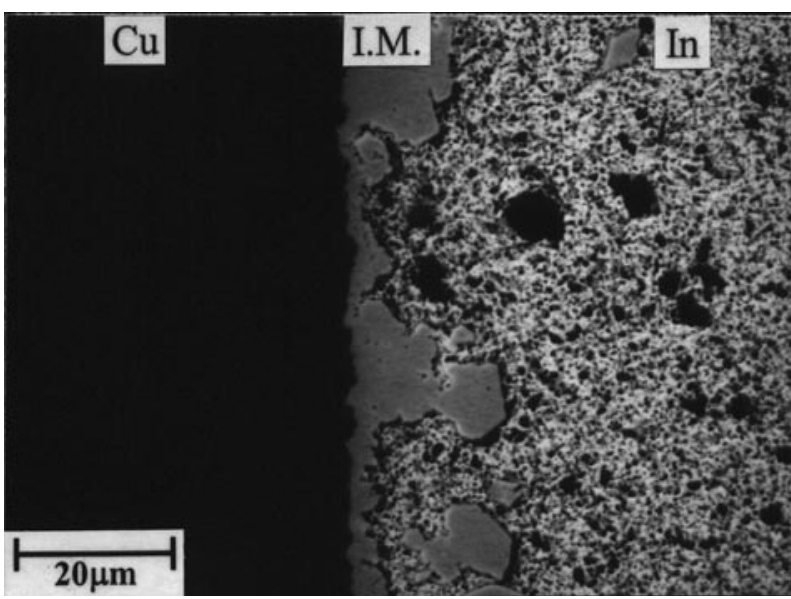

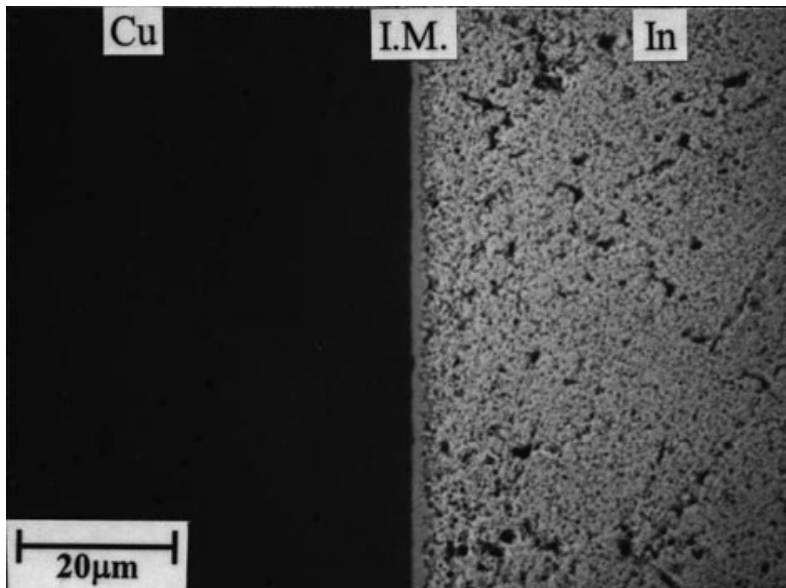

b
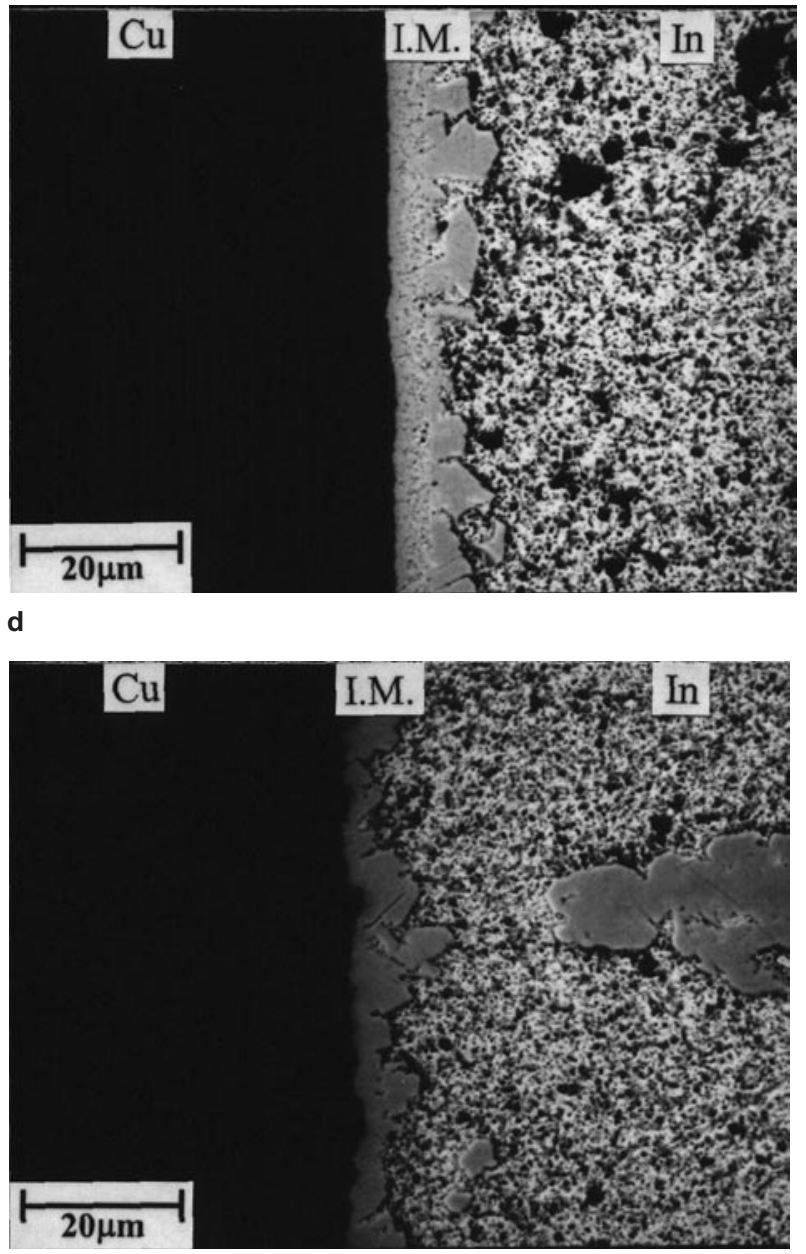

Fig. 1. Microstructures of intermetallic compounds after $\mathrm{Cu} / \mathrm{ln}$ interfacial reactions at various temperatures for $15 \mathrm{~min}$ : (a) $175^{\circ} \mathrm{C},(\mathrm{b}) 200^{\circ} \mathrm{C},(\mathrm{c})$ $250^{\circ} \mathrm{C}$, (d) $300^{\circ} \mathrm{C}$, (e) $350^{\circ} \mathrm{C}$, and (f) $400^{\circ} \mathrm{C}$. 
with $0.3 \mu \mathrm{m} \mathrm{Al}_{2} \mathrm{O}_{3}$ powder. The indium solder was rolled from an In ingot (99.99\% purity) into a $0.3-\mathrm{mm}$ thick foil, and then cut to a size of $7 \mathrm{~mm} \times 5 \mathrm{~mm}$. A rosin mildly actived (RMA) type flux was lightly pasted over the $\mathrm{Cu}$ substrates, and the In foils were laid on the $\mathrm{Cu}$ substrates in an infrared furnace under vacuum of $10^{-3}$ torr. Interfacial reactions were carried out at various temperatures ranging from $175^{\circ} \mathrm{C}$ to $400^{\circ} \mathrm{C}$ for various times.

For scanning electron microscopy morphology observations, the reacted specimens were cut along the cross section, ground with $\mathrm{SiC}$ paper, and polished with $0.3 \mu \mathrm{m} \mathrm{Al} \mathrm{O}_{3}$ powder. A solution of $10 \mathrm{~mL} \mathrm{HF}$, $10 \mathrm{~mL} \mathrm{H}_{2} \mathrm{O}_{2}$, and $40 \mathrm{~mL} \mathrm{H}_{2} \mathrm{O}$ was used to selectively etch out In to reveal the intermetallic compounds. The compositions of intermetallic compounds were analyzed by EPMA. For clarifying the growth mechanism of intermetallic compounds during the interfacial reaction, the $\mathrm{Cu}$ substrate was partially sputter-coated with a Ta thin film that acted as a diffusion marker of the original $\mathrm{Cu} / \mathrm{In}$ interface.

\section{RESULTS AND DISCUSSION}

Figure 1 shows the microstructure of intermetallic compounds (IMs) formed at the $\mathrm{Cu} / \mathrm{In}$ interface after soldering reactions at various temperatures for $15 \mathrm{~min}$. A single layer of the scallop-shaped intermetallic compound appeared at the $\mathrm{Cu} / \mathrm{In}$ interface after soldering as the temperature exceeds $300^{\circ} \mathrm{C}$. Reactions at lower temperatures (below $300^{\circ} \mathrm{C}$ ) result in a double interfacial layer consisting of both continuous and scallop-shaped intermetallic compounds. Such a bilayer of intermetallic compounds is further examined by selective etching of the In solder after interfacial reaction. The result in Fig. 2 indicates that the scallop-shaped intermetallic compound possesses a crystallographic structure, while the continuous layer of the intermetallic compound has a spherical structure. When the copper substrate is partially sputter-coated with a Ta thin film (which acts as a diffusion barrier between $\mathrm{Cu}$ and liquid $\mathrm{In}$ ), the original $\mathrm{Cu} / \mathrm{In}$ interface can be

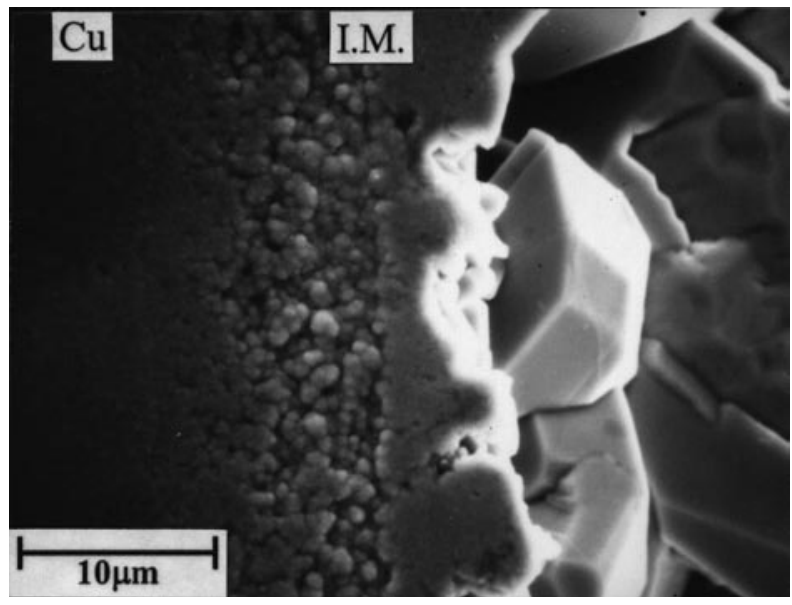

Fig. 2. Micrograph of the intermetallic compound formed at the $\mathrm{Cu} / \mathrm{In}$ interface after soldering reaction at $250^{\circ} \mathrm{C}$ for $120 \mathrm{~min}$ with the In solder selectively etched.

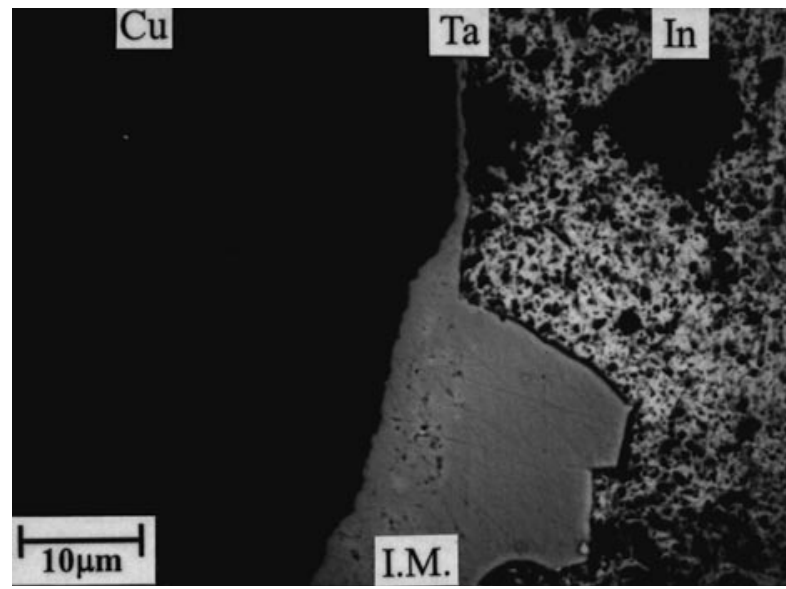

Fig. 3. Formation of different intermetallic compounds on both sides of the $\mathrm{Cu} / \mathrm{In}$ interface marked with Ta thin film after soldering reaction at $250^{\circ} \mathrm{C}$ for $120 \mathrm{~min}$.

marked. Figure 3 indicates that the Ta marker is located right on the line of demarcation between both intermetallic compounds in the double layer. With an increase in reaction time, both intermetallic compounds in the double layer will grow in opposite directions, as shown in Fig. 4. The EPMA analyses of the intermetallic compound formed at higher temperatures show a constant distribution with the stoichiometric composition of $\mathrm{Cu}_{16} \mathrm{In}_{9}$.

A typical result obtained from the specimens reacted at $400^{\circ} \mathrm{C}$ for $120 \mathrm{~min}$ is shown in Fig. 5. The bilayered intermetallic compounds formed in the specimens after soldering reactions at lower temperatures are also analyzed. Figure 6 shows that the scallopshaped intermetallic compound possesses a constant $\mathrm{Cu}$ content of 55 at.\%, which implies a stoichiometric composition of $\mathrm{Cu}_{11} \mathrm{In}_{9}$. Chemical analyses of the continuous intermetallic layer reveal an average composition of CuIn. However, the copper content of such a CuIn intermetallic compound declines slightly toward the In solder, which can be attributed to enrichment of the In element at the boundaries of CuIn spheroids. The result is evidenced by the micrographs in Fig. 2, where the selectively etched gaps between CuIn spheroids extend deeper toward the direction opposite to the copper substrate.

Average thicknesses $(\Delta \mathrm{X})$ of various intermetallic compounds were measured and plotted against the square root of reaction time $(\mathrm{t})$ :

$$
\Delta \mathrm{X}=\mathrm{k}(\mathrm{t})^{1 / 2}
$$

where $\mathrm{k}$ represents the growth rate constant. Figures 7-9 show that the growth of $\mathrm{Cu}_{16} \mathrm{In}_{9}, \mathrm{Cu}_{11} \mathrm{In}_{9}$, and CuIn intermetallic compounds follows a parabolic relationship, implying that the growth of all intermetallic layers is diffusion-controlled. In this case, the Arrhenius equation can be employed to express the growth rate constant for the intermetallic layers:

$$
\mathrm{k}=\mathrm{A} \exp \left(-\frac{\mathrm{Q}}{\mathrm{RT}}\right)
$$

where $\mathrm{A}$ is a constant, $\mathrm{Q}$ the activation energy, $\mathrm{R}$ the 

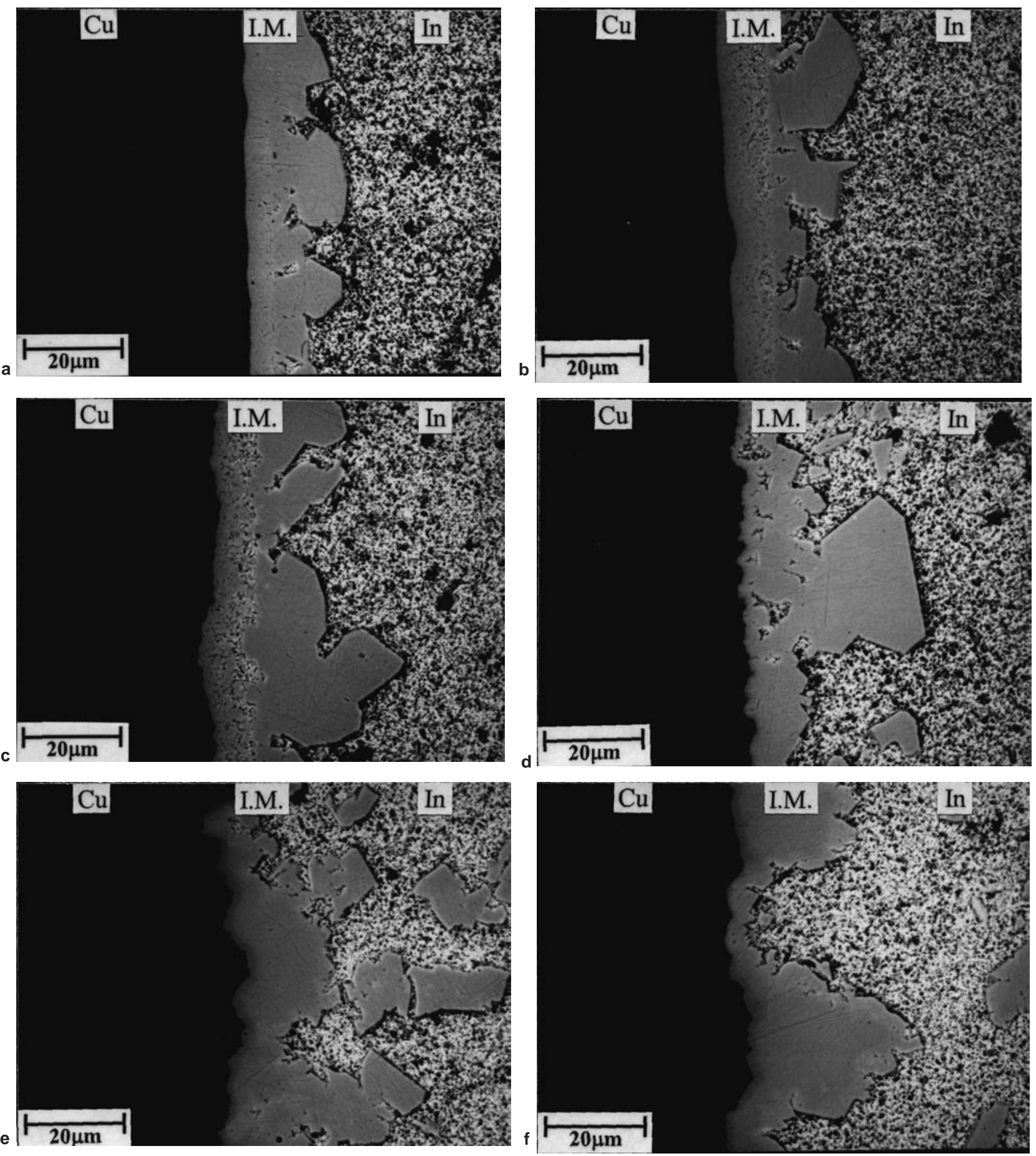

Fig. 4. Microstructures of intermetallic compounds after $\mathrm{Cu} / \mathrm{In}$ interfacial reactions at various temperatures for $120 \mathrm{~min}$ : (a) $175^{\circ} \mathrm{C},(\mathrm{b}) 200^{\circ} \mathrm{C},(\mathrm{c})$ $250^{\circ} \mathrm{C}$, (d) $300^{\circ} \mathrm{C}$, (e) $350^{\circ} \mathrm{C}$, and (f) $400^{\circ} \mathrm{C}$.

gas constant, and $\mathrm{T}$ the absolute temperature. An Arrhenius plot of ln k vs. 1/T for the growth of various intermetallic compounds is given in Fig. 10. The activation energies (Q) for the growth of $\mathrm{Cu}_{16} \mathrm{In}_{9}$, $\mathrm{Cu}_{11} \mathrm{In}_{9}$, and $\mathrm{CuIn}$ as calculated from the plot are $59.5,16.9$, and $23.5 \mathrm{~kJ} / \mathrm{mole}$, respectively.

\section{CONCLUSIONS}

Soldering reactions between liquid In and $\mathrm{Cu}$ substrates at temperatures above $300^{\circ} \mathrm{C}$ result in the formation of a scallop-shaped $\mathrm{Cu}_{16} \mathrm{In}_{9}$ intermetallic compound. Below $300^{\circ} \mathrm{C}$, the scallop-shaped $\mathrm{Cu}_{11} \mathrm{In}_{9}$ and a continuous CuIn compound grow in opposite directions away from the original $\mathrm{Cu} / \mathrm{In}$ interface. Selective etching of the In solder after reaction shows that the CuIn intermetallic compound contains spheroids rich in the In element at the boundaries.

Kinetics analyses show that the growth of $\mathrm{Cu}_{16} \mathrm{In}_{9}, \mathrm{Cu}_{11} \mathrm{In}_{9}$, and $\mathrm{CuIn}$ intermetallic compounds at the $\mathrm{Cu} / \mathrm{In}$ interface is diffusion-controlled with activation energies being 59.5, 16.9, and $23.5 \mathrm{~kJ} / \mathrm{mole}$, respectively. 


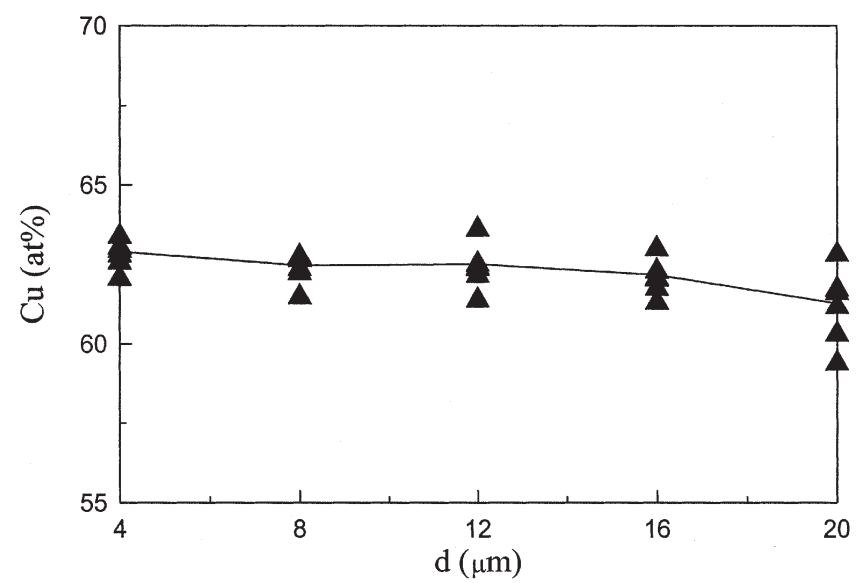

Fig. 5. Copper content of the intermetallic layer formed at $400^{\circ} \mathrm{C}$ for $120 \mathrm{~min}$ as a function of distance (d) from the Cu/IM interface.

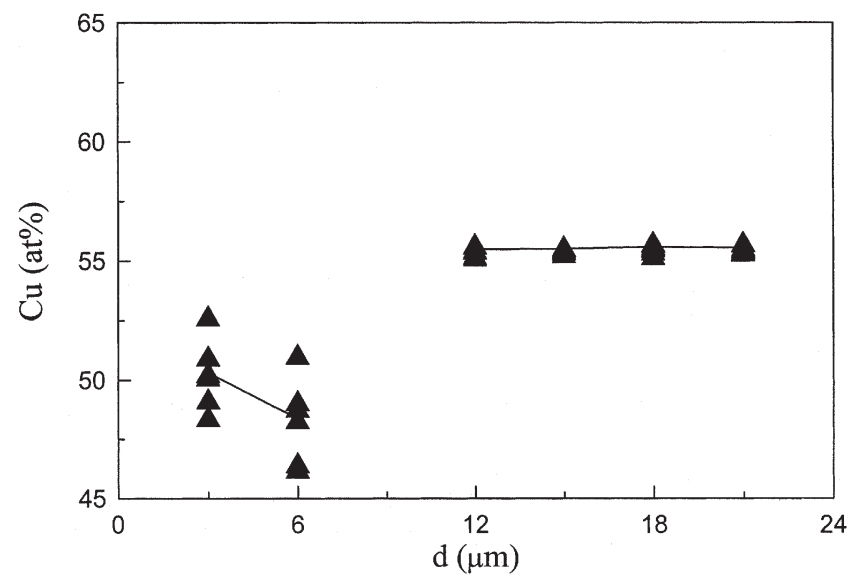

Fig. 6. Copper content of the intermetallic double layer formed at $250^{\circ} \mathrm{C}$ for $120 \mathrm{~min}$ as a function of distance (d) from the $\mathrm{Cu} / \mathrm{IM}$ interface.

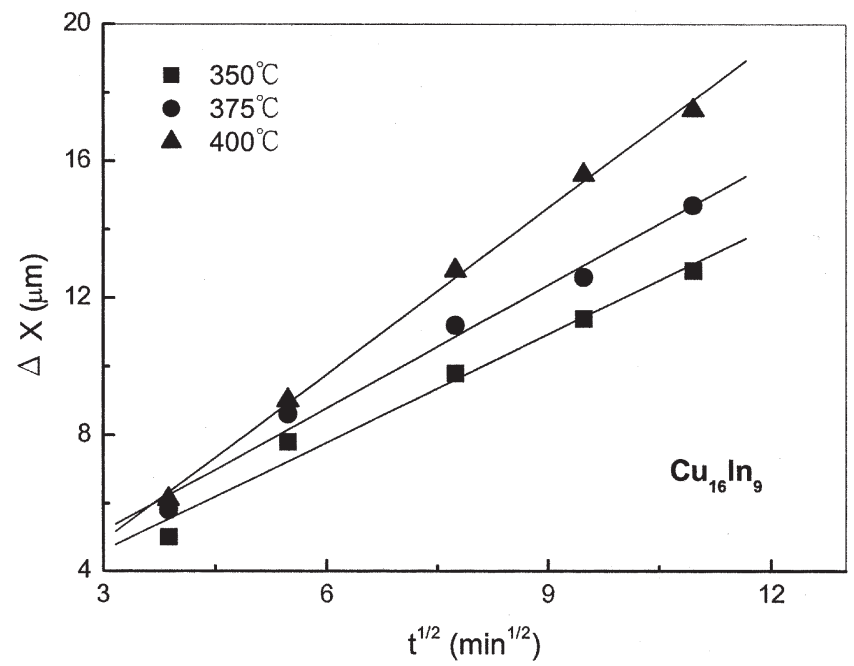

Fig. 7. Average thickness of the $\mathrm{Cu}_{16} \mathrm{In}_{9}$ intermetallic compound $(\Delta \mathrm{X})$ formed at temperatures above $300^{\circ} \mathrm{C}$ as a function of the square root of time $\left(\mathrm{t}^{1 / 2}\right)$.

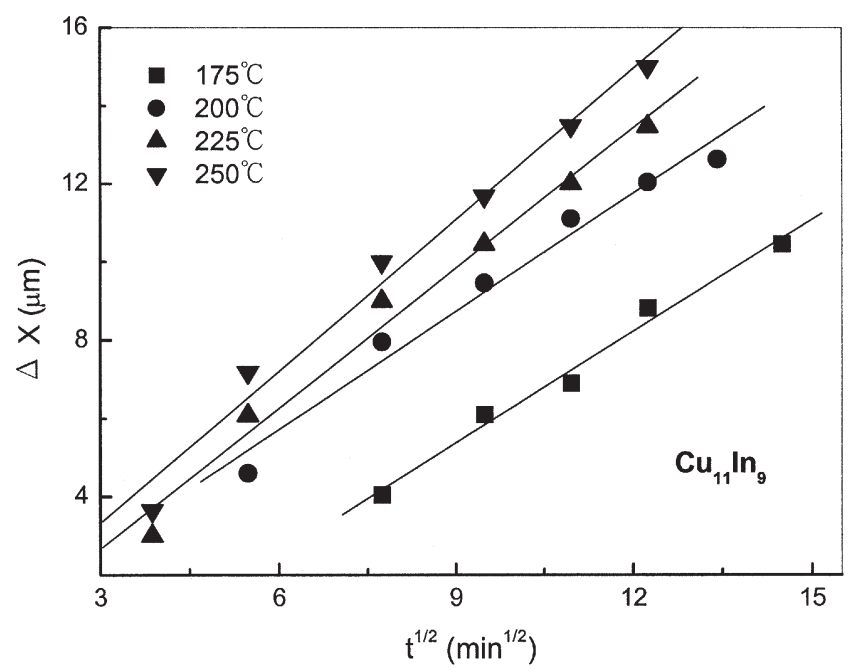

Fig. 8. Average thickness of the $\mathrm{Cu}_{11} \mathrm{In}_{9}$ intermetallic compound $(\Delta \mathrm{X})$ formed at temperatures below $300^{\circ} \mathrm{C}$ as a function of the square root of time $\left(\mathrm{t}^{1 / 2}\right)$.

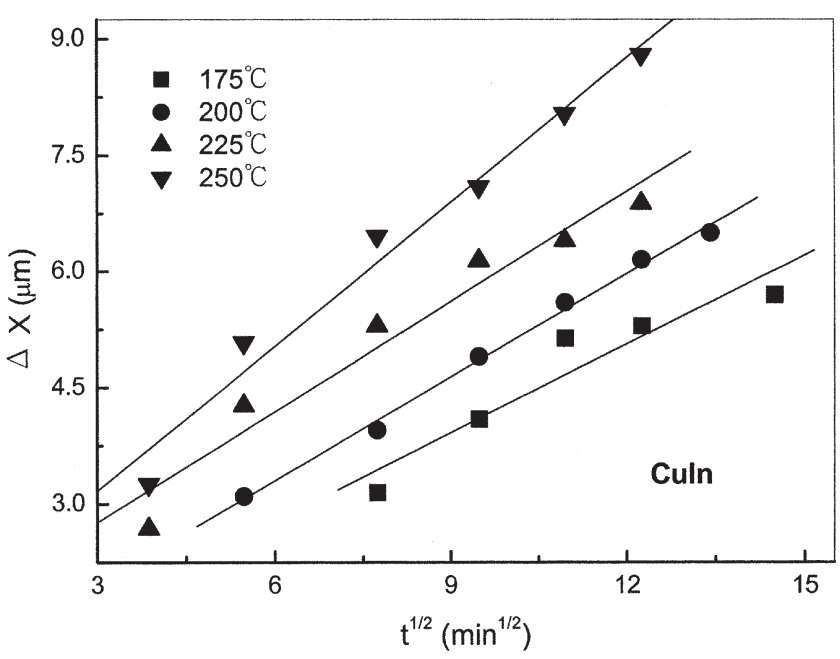

Fig. 9. Average thickness of the Culn intermetallic compound $(\Delta \mathrm{X})$ formed at temperatures below $300^{\circ} \mathrm{C}$ as a function of the square root of time $\left(t^{1 / 2}\right)$.

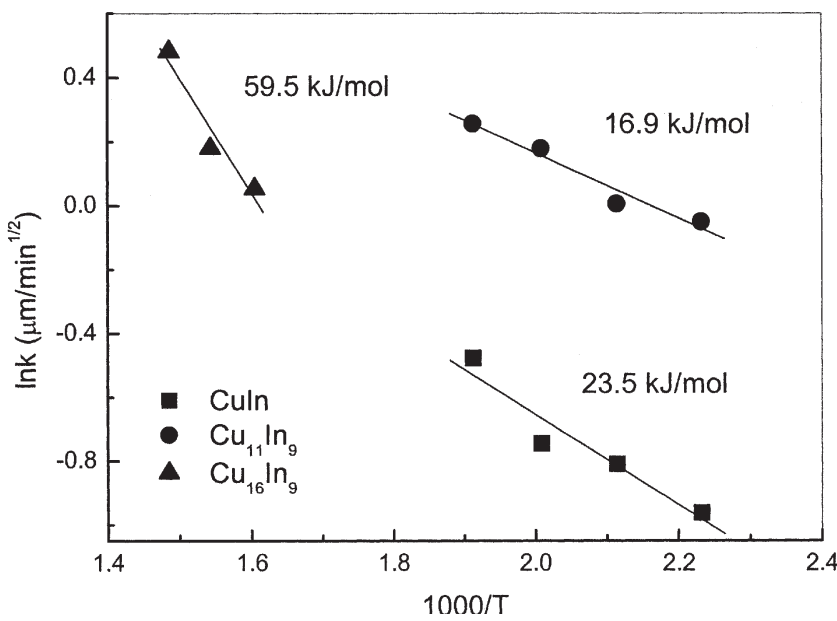

Fig. 10. Arrhenius plots of growth rate constants $(k)$ for various intermetallic compounds formed at the $\mathrm{Cu} / \mathrm{In}$ interface. 
Intermetallic Compounds Formed at the Interface

between Liquid Indium and Copper Substrates

\section{REFERENCES}

1. K. Shimizu, T. Nakanishi, K. Karasawa, K. Hashimoto, and K. Niwa, J. Electron. Mater. 24, 39 (1995).

2. W.K. Jones, Y. Liu, M. Shah, and R. Clarke, Soldering Surface Mount Technol. 10, 37 (1998).

3. L.S. Goldmann, R.D. Herdzik, N.G. Koopman, and V.C. Marcotte, IEEE Trans. Parts, Hybrids and Packaging, PHP-13 3, 194 (1977).
4. P.T. Vianco A.C. Kilgo, and R. Grant, J. Mater. Sci. 30, 4871 (1995).

5. I. Manna, S. Bader, W. Gust, and B. Predel, Phys. Status Solidi (a) 119, K9 (1990).

6. C.R. Kao, Mater. Sci. Eng. A: Struct. Mater.: Prop., Microstr. Processing A23, 196 (1997).

7. L.H. Su, Y.W. Yen C.C. Lin, and S.W. Chen, Metall. Mater. Trans. B 28B, 927 (1997).

8. R. Roy and S.K. Sen, J. Mater. Res. 7, 1377 (1992).

9. Y.C. Chen and C.C. Lee, Thin Solid Films 283, 243 (1996). 